\title{
Tubocurarine Chloride
}

National Cancer Institute

\section{Source}

National Cancer Institute. Tubocurarine Chloride. NCI Thesaurus. Code C47777.

The chloride salt form of tubocurarine, a naturally occurring curare alkaloid isolated from the bark and stem of Chondodendron tomentosum with a muscle relaxant property. Tubocurarine chloride competes with acetylcholine for the nicotinic receptors at the neuromuscular junction of skeletal muscles, thereby inhibiting the action of acetylcholine and blocking the neural transmission without depolarizing the postsynaptic membrane. This may lead to skeletal muscle relaxation and paralysis. 